\title{
Alternative Tillage and Herbicide Options for Successful Weed Control in Vegetables
}

\author{
Russell W. Wallace and Robin R. Bellinder \\ Department of Fruit and Vegetable Science, Cornell University, Ithaca, NY 14853
}

Increased federal and state regulations resulting from concerns for pesticide-free food and protection of ground water have created the need to reevaluate weed control strategies that currently depend on chemicals (Sweet et al., 1990). Cultivation and hand-weeding are feasible for small-scale growers but are usually not economical for large, commercial growers. Weed control in vegetables relies heavily on soil-applied, preemergence herbicides. However, with the development of selective, postemergence herbicides that can be applied as needed, growers may now fine-tune weed control strategies, combining the new herbicides with reduced rates of soil-applied herbicides and cultivation.

Reducing inputs and integrating farming practices to lower costs and reduce environmental impacts while maintaining successful weed control is difficult (Edwards and Regnier, 1989). However, strategies that may reduce chemical inputs include: delaying applications of reduced rates of preemergence herbicides, banding herbicides over the crop row, using mulch and reduced tillage systems that aid in weed suppression, tank-mixing low rates of post- and preemergence herbicides, applying postemergence herbicides after cultivation, and using new, environmentally "soft" herbicides that are active at extremely low doses. The objective of this paper is to discuss previous and current research that integrates tillage, mulches, and low-rate applications of herbicides for use in commercial vegetable production.

\section{Herbicide rate reduction}

The use of low-rate herbicide applications is not new. Akobundu et al. (1975) evaluated low-rates of atrazine and alachlor for postemergence use in sweet corn (Zea mays L. var. saccharata) to reduce carryover and facilitate crop rotation. Recently, successful reduced-herbicide weed control programs have been reported for several crops. When postemergence herbicides were applied twice at one-half to one-fourth $(0.5 x$ to $0.25 x)$ the standard rate $(1 \times)$ in soy- beans [Glycine $\max (\mathrm{L}$.$) Merr.], broadleaf and grass weeds were$ controlled (Defelice et al., 1989). However, when reduced herbicide rates were applied once, weed control was not adequate. Nonselective, postemergence herbicides used in double-cropped, no-till soybeans, may be reduced or eliminated from weed control programs when herbicides having both pre- and postemergence activity are applied (Moseley and Hagood, 1991).

Control of redroot pigweed (Amaranthus retroflexus L.) and common lambsquarters (Chenopodium album L.) in potatoes (Solanum tuberosum L.) was equivalent with both $1 \times$ and $0.67 \times$ rates of oryzalin, metribuzin, and linuron (Wallace and Bellinder, 1990). Similarly, low rates of trifluralin (tomatoes [Lycopersicon esculentum Mill.]) or trifluralin plus oxyfluorfen (cauliflower [Brassica oleracea L. var. botrytis]) provided adequate weed control compared with standard rates (Maynard and Bellinder, 1989).

Cardina et al. (1987) combined reduced rates $(0.67 \times$ to $0.33 \times)$ of benefin and vernolate with multiple postemergence applications of paraquat in peanuts (Arachis hypogaea L.) and found that weed control was equivalent to that of the chemical standard but cost $40 \%$ less. Lanini and Le Strange (1991) reduced preemergence herbicide rates, and when this was coupled with a single hand-weeding, vegetable yields were equivalent to or better than those of the full-rate chemical program or season-long hand-weeding.

While reducing rates may lower the total amount of chemicals applied, control of some weeds may not be satisfactory. Wallace and Bellinder (1990) reported that a reduced rate of metolachlor failed to control redroot pigweed. Tank-mixing two or more herbicides at reduced rates may increase the spectrum of weeds controlled and decrease the risk of inadequate weed control.

Mixing post- and preemergence herbicides increases flexibility in weed management strategies. Shilling et al. (1986) applied diphenamid and glyphosate to cereal grains used for mulches in no-till tobacco (Nicotiana tabacum L.). Glyphosate killed the mulches while 
diphenamid controlled weeds that emerged late, thus reducing the number of applications required.

When cultivation is included in weed control programs, banding herbicides over the crop row at full or low rates will reduce total herbicide use (Putnam, 1990). Where residual herbicides are broadcast, cultivation in the between-row spaces may dilute the herbicide, decreasing its efficacy. When metribuzin or linuron was broadcast in combination with metolachlor and followed by two or more cultivations in potatoes, the number of broadleaf weeds increased above threshold levels (Kain et al., 1986).

Additional research in potatoes has shown that in-row weeds have a more negative impact on yields than do between-row weeds (Lanfranconi, 1991; VanGessel and Renner, 1990). Banding herbicides over the crop row, followed by cultivation between rows, may reduce the need for broadcast herbicides.

\section{"As-needed" herbicide use}

Most weed control programs in vegetables are based on the application of herbicides before crop and weed emergence and are intended to control a broad spectrum of grass and broadleaf weeds. The herbicides used are largely preventative in nature and are often applied to the entire area to be planted, regardless of the different weeds indigenous to individual fields. Applications of herbicides on an "as-needed" basis implies that individual field population differences are both known and can be treated after the weeds appear, on a species-by-species basis. In addition to possible elimination of some herbicide applications, knowledge of the relative quantities of individual weed species aids in potential herbicide rate reductions. Herbicides that can be used on an as-needed basis include those that control weeds pre- and/or postemergence, as well as those with crop selectivity having only preemergence activity (Table 1).

Applying herbicides on an as-needed basis will require regular field monitoring to determine species, numbers, and locations of the weeds. Determining whether or when to cultivate or apply selective herbicides would be important to the success of the program. Cultivation, in the short term, may be cheaper than herbicide applications but may cause pruning of crop roots, dispersal of perennial weed propagules [e.g., quackgrass (Elytrigia repens [L.] Nevski) rhizomes and yellow nutsedge (Cyperus esculentum L.) tubers], increase weed emergence, and dilute preemergence herbicides. Cultivation may provide only

Table 1. Herbicides with potential for use on an as-needed basis in New York.

\begin{tabular}{|c|c|c|c|}
\hline Herbicide & Vegetable & Activity & $\begin{array}{c}\text { Weeds } \\
\text { controlled }\end{array}$ \\
\hline Metribuzin & $\begin{array}{l}\text { Tomatoes, potatoes, } \\
\text { carrots }\end{array}$ & Pre, Post & $\begin{array}{l}\text { Broadleaves, } \\
\text { small grasses }\end{array}$ \\
\hline Linuron & Potatoes ${ }^{\mathrm{Z}}$, carrots & Pre, Post & $\begin{array}{l}\text { Broadleaves, } \\
\text { small grasses }\end{array}$ \\
\hline Metolachlor & $\begin{array}{l}\text { Potatoes, beans, } \\
\text { corn }\end{array}$ & Pre & $\begin{array}{l}\text { Annual grasses, } \\
\text { nutsedge }\end{array}$ \\
\hline Fluazifop & $\begin{array}{l}\text { Processing peas, } \\
\text { carrots }\end{array}$ & Post & $\begin{array}{l}\text { Annual, peren- } \\
\text { nial grasses }\end{array}$ \\
\hline Sethoxydim & Many & Post & $\begin{array}{l}\text { Annual, peren- } \\
\text { nial grasses }\end{array}$ \\
\hline Bentazon & $\begin{array}{l}\text { Beans, corn, } \\
\text { peas }\end{array}$ & $\begin{array}{l}\text { Post } \\
\text { Post }\end{array}$ & $\begin{array}{l}\text { Broadleaves, } \\
\text { nutsedge }\end{array}$ \\
\hline MCPB & Peas & Post & $\begin{array}{l}\text { Broadleaves, } \\
\text { thistle }\end{array}$ \\
\hline 2,4-D & Corn & Post & Broadleaves \\
\hline Oxyfluorfen & Onions & Post & Broadleaves \\
\hline
\end{tabular}

zPreemergent to weeds, postemergent to crop (e.g., after hilling). temporary control, whereas herbicides may provide long-term control (e.g., glyphosate or fluazifop for quackgrass control).

When using the as-needed approach to herbicide use, the appropriate time for herbicide application will vary with the crop and degree of weed pressure. Applications to slowly emerging crops may be delayed, effectively extending the residual weed control period. It is common practice in New York potato production to apply metribuzin or linuron 10 to 14 days after planting but before crop emergence. Both herbicides control small emerged weeds, and provide residual control as well. Wallace and Bellinder (1990) reported good weed control with linuron and metribuzin, even when applied at reduced rates $(0.67 \times)$ (Table 2$)$. When weed populations are low, preemergence herbicides may be reduced or eliminated, and low rates of postemergence herbicides may be applied after cultivation and/or hilling (Lanfranconi, 1991).

Timing of initial herbicide applications varies with cultural practices. The cultural practices and/or botanical characteristics of specific mulches determined the time of metribuzin and sethoxydim applications in strip-tilled tomatoes (Bellinder et al., 1991). Herbicides were applied first 9 days after transplanting (DAT) in oats (Avena sativa L.), and 14 DAT in annual ryegrass (Lolium multiflorum Lam.), red clover (Trifolium pratense L.), and hairy vetch (Vicia villosa Roth). Grain rye (Secale cereale L.) and red fescue (Festuca rubra L.) mulches suppressed weeds for 34 days before treatment was required.

\section{Cover crops and mulches}

Pre- and postplant tillage operations are still considered important for weed control invegetables (Putnam, 1990). However, tillage may cause soil compaction and/or erosion. Tillage may also increase weed emergence (Fig. 1). Cover crops or mulches that decrease erosion and compaction may also suppress weeds. To date, the weed suppression effect of mulches has been little used. Current weed control programs in no-till and stubble-mulch systems recommend the use of nonselective herbicides to kill the cover crop or control emerged weeds in crop residues, followed by preemergence herbicides. Thus, reduced tillage systems often require more herbicides than do conventional systems. Using cover crops that suppress weeds for 4 to 6 weeks after planting (Fig. 2), may reduce the need for full rate, preemergence herbicide programs, despite the need for herbicides to regulate the cover crop.

The use of mulches in commercial vegetable production is limited by several factors. First, crop stand and vigor may be reduced by chemicals released from decomposing residues when direct-seeding small-seeded vegetables into killed mulches. de Almeida (1985) observed that water extracts of several winter crops reduced germi-

Table 2. Comparison of herbicide rates for control of redroot pigweed and common lambsquarters in conventionally grown potatoes (adapted from Wallace and Bellinder, 1990).

\begin{tabular}{lllll}
\hline & \multicolumn{4}{c}{ Rate } \\
\cline { 2 - 5 } Herbicide & $1 x^{2}$ & $0.67 \times$ & \multicolumn{1}{c}{$1 \times$} & $0.67 \times$ \\
\hline & \multicolumn{2}{c}{ Redroot pigweed } & \multicolumn{2}{c}{ Common lambsquarters } \\
1987 & & & & \\
Linuron & 96 & $91^{\mathrm{NS}}$ & 99 & $93^{\mathrm{NS}}$ \\
Metribuzin & 93 & $90^{\mathrm{NS}}$ & 99 & $99^{\mathrm{NS}}$ \\
Oryzalin & 96 & $97^{\mathrm{NS}}$ & 98 & $98^{\mathrm{NS}}$ \\
Metolachlor & 81 & $63^{\mathrm{NS}}$ & 76 & $33^{*}$ \\
1988 & & & & \\
Linuron & 90 & $95^{\mathrm{NS}}$ & 96 & $93^{\mathrm{NS}}$ \\
Metribuzin & 99 & $96^{\mathrm{NS}}$ & 99 & $96^{\mathrm{NS}}$ \\
Oryzalin & 82 & $75^{\mathrm{NS}}$ & 91 & $91^{\mathrm{NS}}$ \\
Metolachlor & 87 & $72^{\mathrm{NS}}$ & 83 & $60^{\mathrm{NS}}$
\end{tabular}

$\mathbf{z}_{1 \times}$ rate is equivalent to label or Cornell recommended rate. $\mathrm{Ns}$, Nonsignificant difference between herbicide rates or significant contrast at $P=0.05$, respectively. 


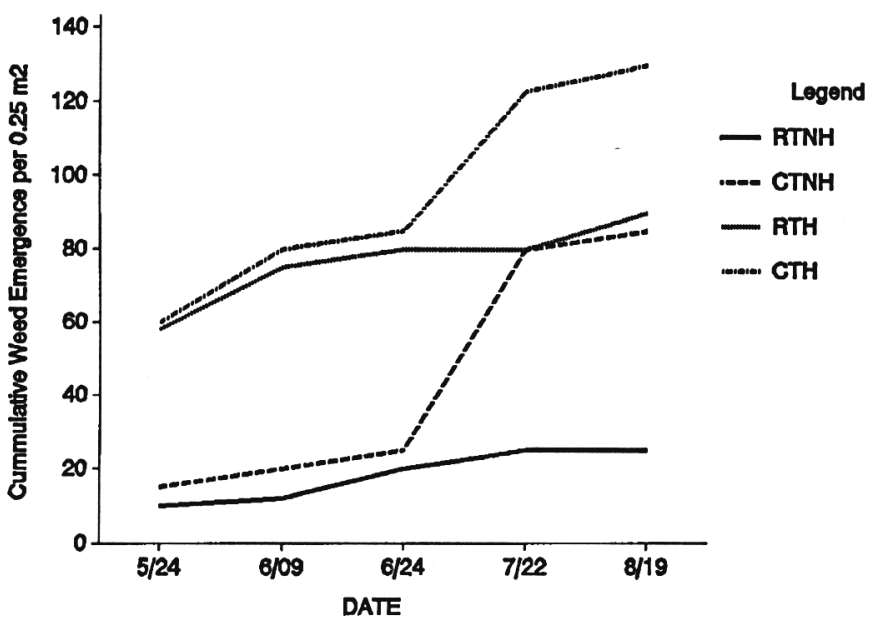

Fig. 1. The effect of reduced tillage and hilling on cumulative weed emergence in potatoes $(\mathrm{CTH}=$ conventional/hilled; $\mathrm{RTNH}=$ reduced tillage/nonhilled) (from Wallace, 1987).

nation and growth of crops such as cotton, rice, beans and corn. However, in field studies, Beste (1973) observed no stand reduction or crop injury in no-till cucumbers (Cucumis sativus L.), tomatoes, or lima beans (Phaseolus lunatus L.).

Second, seeding and transplanting vegetables directly into killed mulches may be mechanically difficult, possibly requiring alterations to machinery (Shelby et al., 1988). Wallace and Bellinder (1989) found that potato stands were reduced $16 \%$ when grown in ryestubble. Aphysical impediment to soil movement caused by the mulch residues resulted in inadequate seed-piece coverage.

Third, changes in soil temperature and moisture levels under the killed mulches may influence crop (Kaspar et al., 1990) and weed emergence (Wallace and Bellinder, 1989). Surface water evaporation is reduced under mulches and during dry seasons, weed seed germination and emergence increase when compared with conventional tillage. Soils with crop residues may also remain cool later in the spring. This may delay crop emergence and cause a shift in weed populations (Table 3).

Research has shown that vegetable weed control can be successful when managed in mulch/reduced tillage systems (Beste, 1973). When perennial weed control and preemergence herbicides were used in notill cabbage (Brassica oleracea var. capitata), weed control and crop yields were equivalent to those of conventional tillage (Bellinder et al., 1984). Redroot pigweed and morning glory (Ipomoea spp.) control 68 and 93 days after no-till tomato transplanting was good with postemergence applications of metribuzin (Shelby et al., 1988). However, annual grass control depended on the graminicide used.

\section{Mulches and low-rate applications: Current research}

Reduced tillage mulch systems coupled with low-rate applications of herbicides have been evaluated for sweet corn (grain rye), snap beans (grain rye), potatoes (grain rye and red clover) and tomatoes (various mulches). Atrazine plus metolachlor was applied preemergence in sweet corn at full (1.1 and $2.2 \mathrm{~kg}$ a.i., respectively), and preand postemergence at half rates to conventional and strip-tillage systems. Weed control was excellent, and yields were equivalent in both tillage systems regardless of herbicide rate or time of application. Where no herbicides were applied, redroot pigweed and common lambsquarters were suppressed $45 \%$ for 6 weeks in the strip-tillage system. Yields of untreated conventional tillage plots were reduced $33 \%$ compared with yields from equivalent strip-till plots.

Weed control in conventional and rye stubble, no-till snap beans did not differ when the full rates of either metolachlor (preemergence, $1.68 \mathrm{~kg}$ a.i.) or bentazon (postemergence, $1.12 \mathrm{~kg}$ a.i.) were applied.

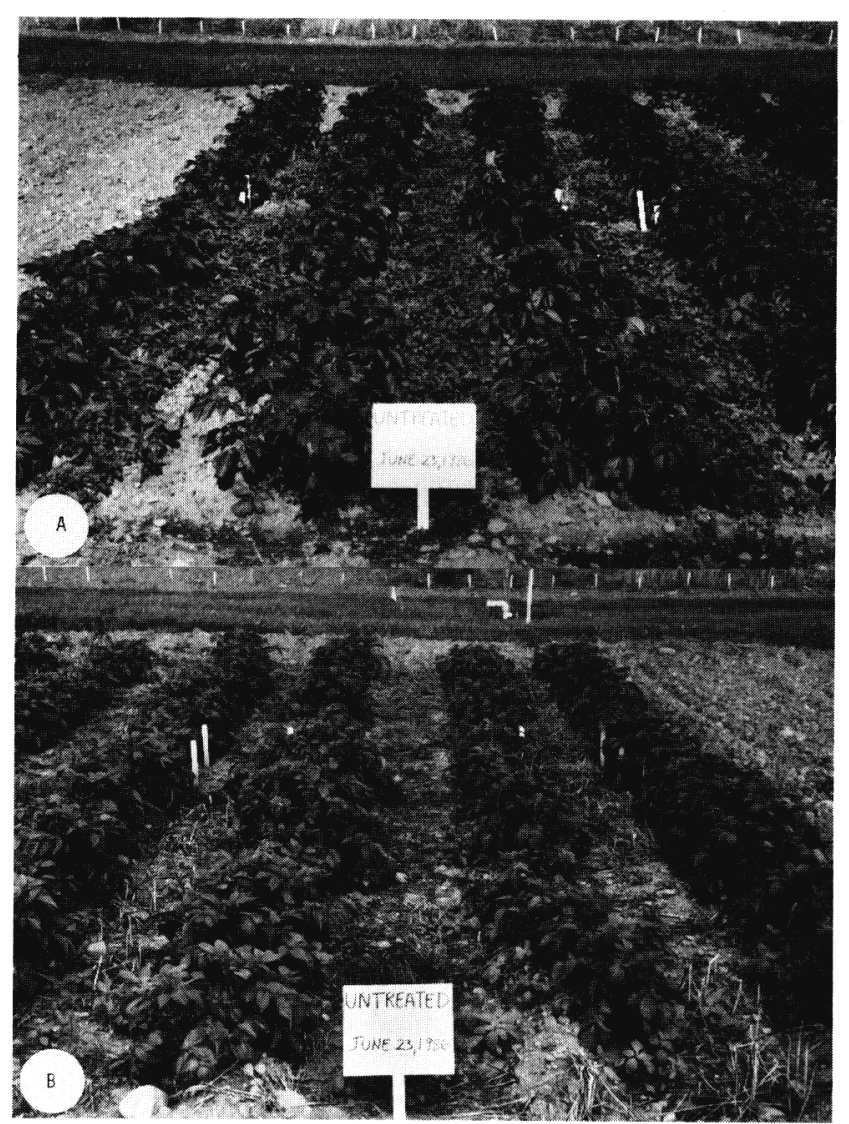

Fig. 2. Comparison of weed populations in conventional (A) and rye stubble reduced tillage (B) potatoes 6 weeks after planting.

However, when cultivation alone was used, weed control decreased $15 \%$ to $20 \%$ in conventionally grown snap beans. Weed control did not decrease when bentazon plus sethoxydim $(0.68$ and $0.24 \mathrm{~kg}$ a.i., respectively) was applied for postemergence. control in the no-till system. The rye residues suppressed redroot pigweed and common lambsquarters $70 \%$ and $85 \%$, respectively, in the untreated no-till system. Snap bean yields were similar, regardless of weed control strategy.

Metribuzin and metolachlor were applied at full- (delayed preemergence 0.56 and $1.68 \mathrm{~kg}$ a.i., respectively) and half-rates (delayed preemergence and after hilling) to potatoes grown conventionally and in a killed, red clover sod. Weed control in both tillage systems was $\geq 88 \%$, regardless of herbicide rate or application time. However, in contrast with work with rye residues, weed populations in untreated red clover were $47 \%$ greater than those in the untreated, conventionally tilled plots. Yields were equivalent where herbicides were used in both tillage systems but were reduced in the untreated red clover plots.

Research in strip-tilled tomatoes evaluated six mulches for ease of regulation and weed control using four posttransplant weed control programs $(0,1 \times, 0.5 \times, 0.33 \times)$ where metribuzin plus sethoxydim was applied on an as-needed basis. Mulches were selected for differing control potentials and included: two winter-killed mulches, spring oats and annual ryegrass; three chemically killed mulches, red clover, grain rye, and red fescue; and one mow-killed mulch, hairy vetch. Glyphosate (1.1 kg a.i./ha) and glyphosate plus 2,4-D (1.1 + $0.84 \mathrm{~kg}$ a.i./ha) were applied to grain rye and red clover, respectively. Red fescue was treated with glyphosate at $2.2 \mathrm{~kg}$ a.i./ha and later with paraquat $(0.56 \mathrm{~kg}$ a.i./ha) just before transplanting. Although winterkilled, annual ryegrass was treated with glyphosate plus 2,4-D to control numerous perennials that had emerged. Conventionally grown 
Table 3. Effect of soil moisture on redroot pigweed and common lambsquarters establishment in conventional and rye stubble, reduced tillage potatoes (adapted from Wallace and Bellinder, 1989).

\begin{tabular}{lcrr} 
& Soil moisture & \multicolumn{2}{c}{ Weeds $/ \mathrm{m}^{2}$} \\
\cline { 3 - 4 } Tillage & $(\%)$ & R. pigweed & C. lambsquarters \\
\hline
\end{tabular}

1985

\begin{tabular}{lrcc} 
Conventional & 9.7 & 8 & 3 \\
Reduced & 12.4 & $16^{*}$ & 4 \\
1986 & & & 110 \\
Conventional & 8.1 & 183 & $42^{* * *}$ \\
Reduced & 7.9 & $40^{* * *}$ & \\
\hline
\end{tabular}

*,***Significantly different between tillage at $P=0.05$ and 0.001 , respectively.

tomatoes were included for comparison.

All mulches were not successfully controlled. At transplanting, mulch regulation was complete only in grain rye, spring oats, and annual ryegrass. Red fescue, red clover, and hairy vetch continued to grow despite regulation attempts. Three weeks after transplanting, mulch cover was greatest in grain rye and red fescue, and lowest in spring oats and annual ryegrass.

Metribuzin and sethoxydim were applied first to spring oat plots 9 days after transplanting (DAT), 14-17 DAT in annual ryegrass, hairy vetch, and red clover. Grain rye and red fescue did not require herbicides until 34 DAT. Additional herbicide applications were required in all annual ryegrass plots, and in the $0.5 \times$ and $0.33 \times$ plots in red clover. Weed control 10 weeks after transplanting generally did not differ between mulch or herbicide program, indicating that using the lower rates did not reduce herbicide efficacy. Weed control costs for each mulch and herbicide program are reported in Table 4.

Weed suppression was greatest in untreated rye and red fescue plots 6 weeks after transplanting, and was least in spring oats and annual ryegrass. Weed populations within untreated plots varied with mulch, indicating that cultural practices and growth habits of the individual mulches may have influenced the colonization of particular weed species. For example, dandelion, wild carrot, and quackgrass were the predominant weeds in red clover, spring oats, and annual ryegrass, respectively.

Tomato yields, averaged across herbicide treatments, were lowest in red clover and red fescue when compared with grain rye treatments. Yields in untreated plots were greatest in grain rye and significantly reduced in red clover, spring oats, annual ryegrass, and conventional tillage.

\section{Summary}

Public concerns over pesticide use have created the need to reevaluateweed control strategies. Cover crops and mulches, combined with the judicious use of herbicides on an as-needed basis, will potentially suppress weeds and reduce herbicide use in vegetables. However, differences in mulch growth habits and regulation may influence mulch performance and the need for subsequent herbicides, and may require substantial machinery modification. Mulches that are winter- or mechanically killed may reduce the need for herbicides required for regulation. However, increased perennial weeds in these mulches (necessitating chemical control) or competitive regrowth of mowed mulches may preclude their use in vegetable production.

\section{Literature Cited}

Akobundu, I.O., R.D. Sweet, W.B. Duke, and P.L. Minotti. 1975. Weed response to atrazine and alachlor combinations at low rates. Weed Sci. 23:67-71.

Bellinder, R.R., T.E. Hines, and H.P. Wilson. 1984. Herbicide pro-
Table 4. Comparative costs of weed control inputs in tomatoes grown conventionally and in six strip-till mulches (adapted from Bellinder et al., 1991).

\begin{tabular}{|c|c|c|c|c|}
\hline \multirow[b]{2}{*}{ Mulch } & \multicolumn{3}{|c|}{ Herbicide program } & \multirow[b]{2}{*}{$0.33 x$} \\
\hline & $0 x$ & $1.0 \mathrm{x}$ & $0.5 x$ & \\
\hline & \multicolumn{3}{|c|}{$\$ / h a^{\mathrm{Z}}$} & \\
\hline Red clover & 141 & 200 & $203^{y, x}$ & $188^{\mathrm{X}}$ \\
\hline Grain rye & 84 & 143 & 136 & 121 \\
\hline Hairy vetch ${ }^{\mathrm{y}}$ & 193 & 252 & 245 & 230 \\
\hline Spring oats & 64 & 124 & 116 & 101 \\
\hline Red fescue & 333 & 393 & 385 & 371 \\
\hline Annual ryegrass & 111 & $180^{\mathrm{X}}$ & $173^{x}$ & $158^{\mathrm{x}}$ \\
\hline Conventional $^{\mathrm{w}}$ & 57 & 116 & 109 & 94 \\
\hline
\end{tabular}

Includes costs of mulches, regulation, and herbicides.

yMow-killed.

x Two applications of herbicides were required.

wPlowed and disked.

grams and tillage systems for cabbage. Proc. Northeastern Weed Sci. Soc. 38:191-194.

Bellinder, R.R., R.W. Wallace, and L.E. Lanfranconi. 1991. Potential herbicide rate reduction utilizing mulch characteristics and management strategies. Proc. Northeastern Weed Sci. Soc. 45:20. (Abstr.)

Beste, C.E. 1973. Evaluation of herbicides in no-till planted cucumbers, tomatoes and lima beans. Proc. Northeastern Weed Sci. Soc. 27:232-239.

Cardina, J., A.C. Mixon, and G.R. Wehtje. 1987. Low-cost weed control systems for close-row peanuts (Arachis hypogaea). Weed Sci. 35:700-703.

de Almeida, F.S. 1985. Effect of some winter crop mulches on the soil weed infestation. Proc. Br. Weed Cont. Conf. 2:651-659.

Defelice, M.S., W.B. Brown, R.J. Aldrich, B.D. Sims, D.T. Judy, and D.R. Guethe. 1989. Weed control in soybeans (Glycine max) with reduced rates of postemergence herbicides. Weed Sci. 37:365374.

Edwards, C.A. and E.E. Regnier. 1989. Designing integrated lowinput farming systems to achieve effective weed control. Proc. Brit. Crop Protection Council, Weeds 2:585-590.

Kain, D.P., J.P. Sciezka, and R.D. Sweet. 1986. Field evaluation of a proposed integrated pest management (IPM) approach to weed control in potatoes. Proc. Northeast Weed Sci. Soc. 40:187-193.

Kaspar, T.C., D.C. Erbach, and R.M. Cruse. 1990. Corn response to seed-row residue removal. Soil Sci. Soc. Am. J. 54:1112-1117.

Lanfranconi, L.E. 1991. Coupling rye (Secale cerale L.) residues to decrease herbicides in reduced tillage potatoes (Solanum tuberosum L.). MS Thesis, Cornell Univ., Ithaca, N.Y

Lanini, W.T. and M. Le Strange. 1991. Low-input management of weeds in vegetable fields. Calif. Agr. 45:11-13.

Maynard, E.T. and R.R. Bellinder. 1989. Can cover crop residues control weeds in vegetable crops? Proc. Northeastern Weed Sci. Soc. 43:150. (Abstr.)

Moseley, C.M. and E.S. Hagood. 1991. Decreasing rates of nonselective herbicides in double-crop no-till soybeans (Glycine max). Weed Technol. 5:198-201.

Putnam, A.R. 1990. Vegetable weed control with minimal herbicide inputs. HortScience 25:155-159.

Shelby, P.P., Jr., D.L. Coffey, G.N. Rhodes, Jr., and L.S. Jeffery. 1988. Tomato production and weed control in no-tillage versus conventional tillage. J. Amer. Soc. Hort. Sci. 113:675-678.

Shilling, D.G., A.D. Worsham, and D.A. Danehower. 1986. Influence of mulch, tillage, and diphenamid on weed control, yield, and quality in no-till flue-cured tobacco (Nicotiana tabacum).

Sweet, R.D., J.E. Dewey, D.J. Lisk, W.R. Mullison, D.R. Rutz, and W.G. Smith. 1990. Pesticides and safety of fruits and vegetables. Council Agr. Sci. and Technol., Comments from CAST 1990-1. 
VanGessel, M. and K.A. Renner. 1990. Redroot pigweed (Amaranthus retroflexus) and barnyard grass (Echinochloa crus-galli) interference in potatoes (Solanum tuberosum). Weed Sci. 38:338-343.

Wallace, R.W. 1987. The influence of reduced tillage management on weed and Colorado Potato Beetle populations and potato yield and quality potential. MS Thesis, Cornell Univ., Ithaca, N.Y.
Wallace, R.W. and R.R. Bellinder. 1989. Potato (Solanum tuberosum) yields and weed populations in conventional and reduced tillage systems. Weed Technol. 3:590-595.

Wallace, R.W. and R.R. Bellinder. 1990. Low-rate applications of herbicides in conventional and reduced tillage potatoes (Solanum tuberosum). Weed Technol. 4:509-513. 